\title{
TRUDNOŚCI ZWIĄZANE Z BADANIAMI ILOŚCIOWYMI W STUDIACH NAD WSPÓLCZESNYMI MIGRACJAMI WYBRANE ZAGADNIENIA
}

\begin{abstract}
Abstrakt. Artykuł ma na celu przybliżenie osobom zainteresowanym ilościowymi badaniami nad współczesnymi migracjami podstawowych trudności, z jakimi trzeba się zmierzyć w tym obszarze badawczym. Najwięcej uwagi poświęcono trudnościom definicyjnym. Problem ten jest wielopłaszczyznowy i poza samymi trudnościami w ustaleniu znaczenia danego terminu w grę wchodzą liczne wpływy o charakterze politycznym (celowościowym), prawnym, praktycznym, procesualnym i temporalnym. Dlatego problematyka ta stanowi również punkt wyjścia dla uwag czynionych w odniesieniu do pomiaru, interpretacji, dostępności, kontrowersji, niespójnych i niskiej jakości informacji zawartych w dostępnych bazach danych. Skutkiem tego jest rozproszenie danych i ich fragmentaryczność, co znacząco wpływa na możliwość prowadzenia badań porównawczych (zarówno między państwami, jak i różnymi kategoriami mieszkańców tego samego kraju). Omówiony został też przykładowy system gromadzenia danych o migracjach zagranicznych. Na zakończenie poczyniono kilka uwag na temat wybranych aspektów samego procesu badawczego, istotnych z punktu widzenia badań nad współczesnymi migracjami. Opis odnoszony jest do kontekstu polskiego i europejskiego.
\end{abstract}

Słowa kluczowe: badania ilościowe, migracje, imigracja, emigracja, bazy danych.

\section{Wprowadzenie ${ }^{1}$}

Problematyka migracji rozwija się już od wielu lat, zarówno w obszarze teorii (stabilnie i progresywnie od teorii neoklasycznej aż do koncepcji transnarodowości, włączając kolejne elementy do analizy), jak i empirii, która będzie głównym przedmiotem niniejszego artykułu. Znaczne zainteresowanie badaniami na temat

* Mgr, doktorant, Katedra Socjologii Sztuki, Instytut Socjologii, Wydział Ekonomiczno-Socjologiczny, Uniwersytet Łódzki, ul. Rewolucji 1905 r. 41/43, 90-214 Łódź; e-mail: jk.adamski@gmail.com.

${ }^{1}$ Wszelkie cytaty pochodzące ze źródeł angielskojęzycznych zostały przetłumaczone na potrzeby artykułu przez autora niniejszego tekstu. 
przemieszczeń ludzi w i między państwami pojawiło się na skutek konsekwencji wywołanych przez określoną politykę imigracyjną i społeczną, wprowadzoną po II wojnie światowej. To właśnie te rozwiązania prawne, w połączeniu z nieprzewidywalnym żywiołem, jakim są ludzie, wymusiły na rządzących konieczność pozyskiwania i reagowania na dane odnośnie do mobilności ludności, zarówno tej w obrębie danego kraju, jak i spoza niego. Sytuacja jest jeszcze bardziej zawiła, jeśli uwzględnimy różnice kulturowe albo cywilizacyjne.

Zakres przydatnych informacji do badania procesów migracyjnych jest szeroki, co implikuje podejście interdyscyplinarne i korzystanie z dziedzin takich jak socjologia, geografia, prawo, stosunki międzynarodowe, politologia itd. wraz z różnymi „subdyscyplinami” - prawo międzynarodowe, socjologia kultury, geografia ekonomiczna, demografia itd. Głównym celem artykułu jest zarysowanie, jakie problemy napotyka badacz, kiedy rozważa przeprowadzenie badań o charakterze ilościowym w obszarze studiów nad współczesnymi migracjami. Owe informacje stanowią główne źródło danych dla decydentów związanych z planowaniem rozwiązań określonych problemów ekonomicznych i społecznych w kraju².

Wobec powyższego artykuł został przygotowany w następujący sposób: w pierwszej kolejności zostaną omówione podstawowe kwestie terminologiczne, aby następnie przejść do problemów dotyczących definiowania pojęć (a więc kluczowego aspektu związanego z każdym badaniem, zwłaszcza zaś ilościowym, gdzie precyzja i zrozumienie tego, co stoi za liczbami, jest wyjątkowo istotne), gdzie konieczne jest również odwołanie się do kwestii prawnych (zwłaszcza prawa międzynarodowego i Unii Europejskiej). W dalszej kolejności został opisany problem fragmentaryzacji baz danych i ich ograniczoności. Na koniec zaś przedstawiono sposoby zbierania określonych informacji na temat migracji wraz z podstawowymi problemami, które powodują.

Mimo iż tekst traktuje o problemach metodologicznych związanych z ilościowym podejściem do badań nad migracjami we współczesnym świecie, nie należy się jednak spodziewać egzemplifikacji czysto technicznych. To znaczy, przedstawione tutaj uwagi będą się raczej odnosiły do ogólnych trudności, nie zaś konkretnych metod, technik czy narzędzi w obrębie perspektywy ilościowej. Każda z tych kategorii posiada swoje własne specyficzne ograniczenia i omówienie dodatkowych komplikacji dla każdej z nich, wiążących się ze studiami nad migracją, zdecydowanie wykracza poza ramy niniejszego tekstu.

2 Warto zauważyć, iż badania jakościowe w obszarze migracji, chociaż prowadzone bardzo często, nie napotykają tak licznych problemów, jak te o charakterze ilościowym. W przypadku tych pierwszych trudności metodologiczne wynikają raczej z samych stosowanych technik niż specyfiki pola badawczego. Zupełnie odwrotnie jest w przypadku badań ilościowych, które nie są tak elastyczne. 


\section{Podstawy terminologiczne}

Gdy przeglądamy literaturę na temat badań nad współczesnymi migracjami, nie ulega wątpliwości, że największy problem stanowią podstawy terminologiczne. Są one bazą wszystkich pozostałych trudności, na jakie napotka badacz w tym obszarze zainteresowania. Oczywiście kwestie definicyjne zyskują status komplikacji pod wpływem określonych zabiegów i procesów, o których będzie traktowała następna część artykułu. W tym miejscu warto jednak przedstawić w ogólnym zarysie najbardziej podstawowe pojęcia, które dostarczą niezbędnej ramy dla dalszych (sprzężonych ze sobą) rozważań.

W pierwszej kolejności należy rozważyć trzy pojęcia: „migrant” („migracja”), ,imigrant” (,imigracja”) oraz „emigrant” (,emigracja”). Pierwsze z nich oznacza osobę, która przemieszcza się w obrębie terytorium danego państwa lub poza jego granice na dłuższy czas (z reguły taką granicę wyznacza okres jednego roku). Drugi z wymienionych terminów odnosi się do osoby przybywającej do danego kraju, z innego, wcześniej zamieszkiwanego (cezurę wyznacza faktyczny lub zamierzony pobyt przekraczający okres 12 miesięcy). Ostatnie pojęcie zaś odnosi się do osoby opuszczającej dany kraj w celu zamieszkania za granicą przynajmniej 12 miesięcy (EMN 2014: 94-95, 157, 187, 190). Chociaż definiowanie tych terminów może się wydawać trywialne, ma kluczowe znaczenie dla pomiaru mobilności ludności. Oczywiste jest, że dana osoba może być określana wszystkimi tymi słowami - w zależności od kontekstu, czasu, zdarzenia (wyjazd/przyjazd) czy też podmiotu wypowiadającego się (Polak migrujący za granicę będzie dla Polaka pozostającego w kraju emigrantem, natomiast dla mieszkańca kraju przyjmującego imigrantem, a w ogólnym ujęciu sprawy - migrantem).

Kolejną triadę pojęć podstawowych dla badań ilościowych nad migracją stanowią: „zasób migracyjny” (migrant stock), „strumień migracyjny” (migration flow) oraz „migracja netto" (net migration). Pierwsze z wymienionych to po prostu całkowita liczba migrantów (międzynarodowych) w danym kraju (obszarze, regonie) w momencie przeprowadzania badania (dla ostatniego roku). Strumień migracyjny obejmuje z kolei liczbę migrantów (międzynarodowych) przekraczających daną granicę (z reguły państwową, ponieważ raczej nie prowadzi się statystyk dla przemieszczeń między regionami czy też obszarami administracyjnymi; podobnie kwestia ta wygląda w przypadku zasobów migracyjnych) w danym okresie czasu. Tym razem wobec tego uwzględniony czas wykracza poza jednodniowy stan ilościowy obcokrajowców. Ostatni termin oznacza różnicę między imigracją (napływ obywateli innych państw) a emigracją (odpływ obywateli danego państwa ${ }^{3}$ ) na przestrzeni wyznaczonego w badaniu okresu (t a m ż e: 188 , 192, 203; Henning, Hov y 2011: 981; Vargas-Silva 2012: 2-3).

${ }^{3} \mathrm{~W}$ tym przypadku należy też wziąć pod uwagę, iż liczony jest również odpływ imigrantów mieszkających przez jakiś czas w tym kraju. Chodzi tutaj przede wszystkim o pełnienie przez dane państwo roli tranzytowej (tj. kiedy jest ono jedynie niezbędnym przystankiem przed dalszą migracją). 
Przedstawione tutaj pojęcia stanowią szkielet dalszych rozważań, które będą dzieliły i problematyzowały te ogólne kategorie. Zarysowują się już jednak wstępnie pierwsze trudności. Przede wszystkim kwestia pomiaru i tego, co badamy. Dla przykładu, zasób migracyjny sprawdza jedynie zarejestrowanych migrantów (przebywających legalnie, takich, którzy starają się o legalny pobyt lub takich, którzy prawo do legalnego pobytu utracili). Pozostaje zatem liczna kategoria pozostałych imigrantów. Wliczane są także osoby przebywające w danym państwie na zasadzie tranzytu, zostaje wykluczona część migrantów cyrkulacyjnych itd. Strumienie migracyjne również pomijają niektóre kategorie migrantów, np. tych nielegalnych, którzy umykają kontroli granicznej. Samo określenie tego, kim jest migrant, tworzone na podstawie konkretnej ilości czasu (lub - co gorsza - intencji) spędzonej w danym kraju zdaje się arbitralna i sztuczna (chociaż ten problem daje się częściowo rozwiązać, o czym w dalszej części tekstu). Problemów jest jednak znacznie więcej.

\section{Trudności definicyjne i problematyzacja podstawowych kategorii}

Definicje wykorzystywane w „badaniach” nad migracjami podlegają licznym wpływom. Przede wszystkim będzie to określone zapotrzebowanie na dane (tj. zależne od specyfiki procesów mobilności ludzi w danym kraju), zobowiązania prawne, zmiany charakteru procesów migracyjnych, względy naukowe i praktyczne (z metodologicznego punktu widzenia - a zatem możliwości co do sposobu zbierania danych) oraz upływ czasu i zmiany w nim zachodzące (jako kategoria połączona ze zmianą wzorców migracyjnych i jednocześnie od niej odrębna). Nie jest łatwo oddzielić od siebie poszczególne obszary wpływu, jednak dla pewnej przejrzystości taka próba zostanie poczyniona.

\subsection{Zapotrzebowanie na (określone) dane}

Migracje są sprawą polityczną, nie ma co do tego wątpliwości. Zapotrzebowanie na określone dane jest kierowane potrzebami państwowymi w zakresie planowania i wdrażania polityki imigracyjnej i społecznej (D z i ę gle w sk i 2012: 7). W Polsce zbieraniem takich informacji zajmuje się m.in. Główny Urząd Statystyczny (GUS). Przykładowo, w Polsce po 2004 r. w ramach zbierania podstawowych statystyk uwzględniono dodatkowo kwestie związane z migracjami powrotnymi (GUS 2011: 9). Z kolei w Wielkiej Brytanii, gdzie istnieje szczególnie wysoki odsetek migrantów o nieuregulowanym pobycie, punkt ciężkości w badaniach został położony na charakterystykę tej właśnie zbiorowości. Wskazano wówczas, iż w przypadku tego kraju mniejszy problem stanowi nielegalny przyjazd, a większość nielegalnych imigrantów została nimi wtórnie poprzez wy- 
gaśniecie (i nieprzedłużenie) wizy. Dlatego też statystyki związane z tą kategorią obcokrajowców stoją na wyższym poziomie niż w reszcie Unii Europejskiej (Vollmer 2011: 3-4). Również organizacje ponadnarodowe mają określone zapotrzebowanie na informacje. Mowa tutaj przede wszystkim o takich ciałach, jak: Organizacja Narodów Zjednoczonych (ONZ/UN), Unia Europejska (UE) czy Organizacja Współpracy Gospodarczej i Rozwoju (OWGiR/OECD). Wszystkie one tworzą własne definicje, ale także czerpią ze „słowników” innych organizacji. Co ciekawe, dwa wydziały UE (dokładniej - Komisji Europejskiej), tj. European Migration Network (EMN) i Eurostat, dostarczają (odpowiednio: promowanych i obowiązujących) zbiorów definicji terminów wykorzystywanych w badaniach (przede wszystkim statystycznych) nad migracjami. Nie jest jednak tak, iż są one ze sobą tożsame. Przykładowo, pojęcie: „pracownik migrujący” (migrant worker w EMN i migrant workers w Eurostacie) jest definiowane inaczej i tym samym inne jest źródło jego znaczenia (EMN 2014: 189; Eurostat 2015). Wymienione organizacje (włącznie z Eurostatem) prowadzą działania harmonizacyjne w celu ujednolicenia i zobowiązania ich członków wspólną siatką pojęciową (o czynieniu zadość warunkom umów międzynarodowych będzie mowa w kolejnej sekcji). Wobec tego państwa są zobowiązane do gromadzenia odrębnych statystyk dla tych organizacji i - jak łatwo zrozumieć - porównywalność danych nierzadko bywa utrudniona, a o nią przecież chodzi: o porównanie stanów i trendów poszczególnych państw członkowskich w celu wypracowania rekomendacji, programów pomocowych, unaocznienia problemów i słabych ogniw. Jeszcze inne zapotrzebowanie na dane ilościowe mają badacze w naukach społecznych. Właśnie ich pozycja jest relatywnie najbardziej upośledzona, ponieważ, jak zostanie pokazane w dalszej części artykułu, sensowne informacje (tj. gromadzone na poziomie całego kraju) są rejestrowane dla potrzeb administracji, nie zaś nauki, co ogranicza zdecydowanie zasięg analiz. Definicje zatem będą dostosowane do wymogów poszczególnych odbiorców zgodnie z ich potrzebami lub zobowiązaniami, co często może oznaczać niezgodność z rzeczywistością i realnym zapotrzebowaniem danego państwa (J a źw ińs ka 2000: 14).

\subsection{Zagadnienia prawne}

Problem zobowiązań prawnych został już poruszony. W tej sekcji za przykład będzie nam służyła Polska. Jako państwo członkowskie wielu organizacji międzynarodowych i ciał ponadnarodowych jest ona zobowiązana do przestrzegania zawartych umów międzynarodowych (które mają wysoką rangę w źródłach prawa). Umowy i porozumienia podpisywane w ramach tych organizacji zawierają zwykle jakiś dokument mówiący o tym, jakich statystyk należy dostarczyć, wraz z podaniem właśnie zestawu pojęć z obowiązującymi definicjami, a także wymogi co do metodologii (np. sposób doboru próby czy wymóg reprezentatywności). 
Wymienione w poprzedniej sekcji organizacje mają swoje wydziały statystyczne, które organizują i koordynują zbieranie danych w porozumieniu z narodowymi ośrodkami statystycznymi (np. Badanie Aktywności Ekonomicznej Ludności - BAEL, przygotowywane dla Międzynarodowej Organizacji Pracy). Nieco inaczej wygląda kwestia związana z członkostwem w UE, gdzie (poza wspomnianym wcześniej przykładem EMN i Eurostatu) dochodzą działania o charakterze prawnym znacznie bardziej ingerujące w krajowy porządek prawny. Odwołując się do słownika wypracowanego przez EMN, możemy zauważyć, że niektóre definicje pochodzą z „rozporządzeń” (regulations), „dyrektyw” (directives), „decyzji” (decisions) oraz innych aktów prawnych (np. konwencji, protokołów itd.). Tą ostatnią kategorię konstytuują przede wszystkim zobowiązania zaciągane przez UE jako taką (co jest związane z opisanymi powyżej skutkami). Ponadto, definicje mogą pochodzić $\mathrm{z}$ aktów prawnych nieodnoszących się bezpośrednio do statystyk, ale zawierających określone znaczenie danego terminu (może być wykorzystane bezpośrednio, jak też stać się podstawą lub inspiracją). Nie wdając się zanadto w szczegóły, warto zwrócić uwagę na „dyrektywy” i ,rozporządzenia". Pierwsze jest aktem harmonizującym prawo, a jego treść ma zostać transponowana do porządku krajowego, tj. ,[z]obowiązuje państwa członkowskie do odpowiedniej implementacji” (Barcz, Górka, Wyrozumska 2014: 238). Oznacza to zatem, że ustawodawca krajowy ma możliwość dostosowania w pewnym stopniu wdrożenia tego prawa. Rozporządzenie, z drugiej strony, jest instrumentem ujednolicania prawa i ,[o]d momentu wejścia w życie [...] stanowi część prawa krajowego [...] i jest stosowane bezpośrednio, bez potrzeby transponowania" (t a m że: 237). Uwagi te są o tyle istotne, że pokazują, jak duży wpływ na zbieranie danych na temat migracji ma prawo oraz stopień związania nim danego państwa czy organu. W przypadku dyrektyw pozostawiono ustawodawcy krajowemu pewną swobodę, chociaż prawdopodobnie elementy takie jak definicje nie są naruszane. Zobowiązania o charakterze prawnym stanowią zatem trzon, jeśli chodzi o statystyki krajowe (warto zaznaczyć, że w przypadku Polski członkostwo w UE jest bardzo ważne, ponieważ materia regulowana przez ustawodawstwo wspólnotowe nie podlega następnie regulacji krajowej, tj. unormowanie dotyczące statystyk migracyjnych jest obowiązujące w brzmieniu wprowadzonym prawem unijnym i nie podlega zmianie (dosłownie w przypadku rozporządzenia i z możliwością dostosowania w przypadku dyrektyw).

Jest jasne, że dane ilościowe zbierane regularnie na poziomie całego kraju zależą od władz państwowych, które poprzez rozbudowany system administracji publicznej i wyspecjalizowane agendy są w stanie logistycznie i finansowo udźwignąć takie przedsięwzięcie. Prawo definiuje podstawowe kategorie, jak np. kto jest emigrantem, uchodźcą, imigrantem, kto przebywa legalnie, a kto nie. Bezpośrednio wpływa to na pozyskiwane dane i ich rzetelność - określa, jakie kategorie są badane, pod względem jakich cech, a także które zbiorowości są wykluczane ze statystyk (chociaż oczywiście nie jest to zamierzone). 


\subsection{Zmiany procesów migracyjnych}

Wzorce migracyjne ulegają zmianom. Rozwój technologii, nagłe wahania na rynku, katastrofy naturalne, przełomy polityczne - wszystkie te zjawiska mogą zmienić charakter i sposób mobilności ludności, powodując przy tym powstawanie nowych typów migracji. Często takie zmiany pociągają za sobą konieczność uzupełnienia już istniejących definicji. Co więcej, rozwój nauki, badań i teorii jest w stanie wykazać nieaktualność pewnych koncepcji. Innymi słowy, rozwój procesów migracyjnych wymaga ciągłej aktualizacji siatki pojęciowej.

\subsection{Względy naukowe i praktyczne}

Definicje, o których tutaj mowa, służą przede wszystkim celom administracyjnym i względnie poszerzeniu wiedzy dla celów polityki społecznej i imigracyjnej. Stąd też ich konstrukcja musi poddawać się prostej operacjonalizacji, a dalej - dane badanie musi być realne z punktu widzenia logistyki i metodologii. Bardziej złożone, opisowe definicje są spotykane w teoriach na temat migracji, ale nawet one powinny do pewnego stopnia uwzględniać faktycznie dostępne dane, które można wykorzystać.

\subsection{Uplyw czasu}

W tym miejscu chodzi raczej o ogólną uwagę związaną z istniejącymi opracowaniami zawierającymi dane statystyczne, ilościowe. Niezależnie od tego, czy będzie to raport z badań, czy artykuł, wszystkie one odnoszą się do definicji, które już mogą być nieaktualne, ponieważ np. nowe rozporządzenie unijne je zmieniło. Co więcej, biorąc pod uwagę zmiany, jakie zaszły między „Spisem Powszechnym” w Polsce między rokiem 2002 a 2011 (GUS 2011: 7-9), widać, że kwestionariusze są uzupełniane zarówno pod wpływem określonego zapotrzebowania na dane, jak i pod wpływem przemian w procesach migracyjnych. Niekiedy zmianie ulega sama metodologia badania, np. zmienia się sposób doboru próby między edycjami. $\mathrm{Z}$ pewnym dystansem należy zatem podchodzić do informacji zawartych w literaturze na temat badań nad migracją i nieustannie je weryfikować, aby „być na bieżąco". Wymiar temporalny ma jeszcze inne znaczenie - mianowicie, trzeba pamiętać o wydarzeniach wyjątkowych i nieprzewidywalnych. Można posłużyć się przykładem hiszpańskiej czy włoskiej polityki imigracyjnej, gdzie co jakiś czas dokonuje się zabiegów abolicyjnych. Skutkuje to tym, iż z dnia na dzień zasób migracyjny powiększa się o kilka, kilkadziesiąt, a nawet kilkaset tysięcy osób, co wynika z faktu odgórnej legalizacji pobytu migrantów nielegalnych, dzięki czemu nagle stają się widoczni dla statystyk. Takie wydarzenia poważnie zaburzają analizy, wywołując nawet konieczność pominięcia albo danego rocznika, albo całego państwa. 
Żeby zrozumieć, jak trudna i wewnętrznie sprzężona jest problematyka terminologii w badaniach nad migracją, warto odnieść się do tego, jak problematyzowane są poszczególne pojęcia podstawowe. Migracja sama w sobie nie jest zjawiskiem jednorodnym, można wyróżnić kilka jej typów: wewnętrzna vs. zewnętrzna, tymczasowa vs. trwała, legalna vs. nielegalna, a także dobrowolna vs. przymusowa (King 2012: 8). Omawiając po kolei:

- Wewnętrzne/zewnętrzne - zgodnie z definicją opracowaną przez GUS ,migracje wewnętrzne” to: ,[z]miany miejsca zamieszkania (pobytu stałego lub czasowego) w obrębie kraju, polegające na przekroczeniu granicy administracyjnej gminy, w tym: w przypadku gmin miejsko-wiejskich - zmiany miejsca zamieszkania w obrębie gminy, z terenów wiejskich na miejskie lub odwrotnie" (GUS 2015). Brakuje, niestety, znaczenia tego pojęcia w słownikach EMN, Eurostatu czy OWGiR. Podobnie zresztą sytuacja wygląda w przypadku definicji „migracji zagranicznych" (zewnętrznych/międzynarodowych). GUS przypisuje im następujące znaczenie (wywiedzione jednak z rekomendacji ONZ): „[w]yjazdy za granicę i przyjazdy do kraju w celu osiedlenia się (zamieszkania na stałe) lub na pobyt czasowy" (GUS 2015 za UN 1998: 9). Te statystyki są stosunkowo proste, ponieważ w przypadku migracji zagranicznych samo pojawienie się na granicy i jej przekroczenie powoduje zarejestrowanie tego faktu (rzecz jasna chodzi tutaj jedynie o migrację legalną, gdyż nielegalna ze swej natury jest nierejestrowana). $\mathrm{W}$ przypadku migracji wewnętrznych również pojawia się problem, ponieważ zasadniczo nie ma punktów rejestracji mobilności ludzi z miasta do miasta czy z gminy do gminy. Nie wszyscy dokonują przemeldowania (zależy to z całą pewnością od długości pobytu), a właśnie przede wszystkim stąd wiadomo, czy dana osoba się przemieściła. Ponadto, nie wszyscy migranci zagraniczni przestrzegają obowiązku zameldowania się w gminie podczas pobytu dłuższego niż 3 miesiące, tak samo, jak nie wszyscy emigranci czynią zadość obowiązkowi wymeldowania (GUS 2011: 4). Jak widać, podział ten nastręcza kolejnych problemów, związanych głównie z pomiarem zasobów i strumieni, przy uwzględnieniu zapotrzebowania administracyjnego, opartego na terminach zdefiniowanych prawnie.

- Tymczasowe/trwałe - nie jest łatwo odnaleźć w słownikach różnych organizacji, czym są „migracje na pobyt stały” (trwałe) spośród wymienionych już źródeł, można ją jednak odnaleźć w wersji proponowanej przez GUS: „,[m]igracje związane ze zmianą miejsca zamieszkania na pobyt stały. W świetle prawa polskiego migracje związane $\mathrm{z}$ dokonaniem $\mathrm{w}$ biurze ewidencji ludności: zameldowania na pobyt stały po przybyciu z innego miejsca w kraju lub z zagranicy; wymeldowania związanego z wyjazdem za granicę na pobyt stały" (GUS 2015). Jest to zatem ujęcie tego terminu jako pewnego działania o charakterze formalnym, prawnym. Tam również można odnaleźć bardzo proste rozumienie tego, czym są „migracje na pobyt czasowy” (tymczasowy): ,[m]igracje na pobyt czasowy trwający powyżej 3 miesięcy" (GUS 2015). Warto jednak sięgnąć do definicji wypracowanej przez EMN, gdzie ujmowana jest ona jako: ,[m]igracja w związku z konkretnym 
motywem i/lub celem, z intencją, że później powróci się do kraju pochodzenia lub wyruszy dalej" (temporary migration) (EMN 2014: 281). Jest to stosunkowo ogólne i niedookreślone pojęcie, zwłaszcza w kontekście tego, jakie informacje są dostępne w bazach danych (o czym będzie mowa w dalszej części artykułu). Migracje tymczasowe zawierają w sobie jednak jeszcze dodatkowy podział, który jest z punktu widzenia terminologii interesujący, mianowicie na „migrację krótkoi długookresową" (short-, long-term migration). Ciekawe jest to, że zarówno GUS, jak i EMN wywiedli swoje definicje $\mathrm{z}$ tego samego źródła - rekomendacji ONZ (EMN również z OWGiR). GUS stwierdza w pierwszym przypadku lakonicznie, że są to: ,[m]igracje na okres od 3 do 12 miesięcy” (GUS 2015 za UN 1998: 10). Znacznie bliższa oryginałowi jest jednak definicja wywiedziona przez EMN: „[p]rzemieszczanie się jednostek, które zmieniają państwo zwyczajowego pobytu na okres przynajmniej trzech miesięcy, ale na mniej niż jeden rok (12 miesięcy), z wyłączeniem przypadków, kiedy przemieszczenie do tego kraju ma na celu rekreację, urlop, odwiedziny przyjaciół lub krewnych, leczenie lub pielgrzymkę religijną" (EMN 2014: 266). Definicja wypracowana przez ONZ, zawiera dodatkowe zdanie odnośnie rozumienia $\mathrm{w}$ tym przypadku pojęcia „Zwyczajowe miejsce pobytu”. Podobnie wygląda sytuacja w przypadku "migracji długookresowych” - dla GUS są to: ,[m]igracje na co najmniej 12 miesięcy” (GUS 2015 za UN 1998: 10). Ponownie wierniejsza oryginałowi jest definicja wywiedziona przez EMN: ,,[p]rzemieszczanie się jednostek, które zmieniają państwo zwyczajowego pobytu na okres przynajmniej jednego roku, tak że kraj docelowy efektywnie staje się ich nowym krajem zwyczajowego pobytu" (EMN 2014: 181) (oryginalne znaczenie zawiera jedno dodatkowe zdanie, jednak niezbyt istotne). Brzmienie zgodne z pierwotną wersją obu terminów przyjęło OWGiR. Co ciekawe, Eurostat posiada jedynie definicję migracji długookresowej, lecz jest ona ukryta pod pojęciem „migracja” (migration) i brzmi: ,[d] tugookresowy międzynarodowy migrant to osoba, która przemieszcza się do kraju innego niż ten, w którym on/ona zwyczajowo przebywa, na okres przynajmniej roku (12 miesięcy), tak że kraj docelowy efektywnie staje się jego lub jej nowym krajem zwyczajowego pobytu" (Eurostat 2015). Interesujące, iż jako źródło nie są podawane tutaj rekomendacje ONZ, chociaż tekst do złudzenia przypomina definicje cytowane wcześniej. Jak zatem widać, niekiedy dany termin jest rozumiany przez wiele podmiotów niemal tak samo. W przypadku GUS zmiana jest istotna, ponieważ pominięto całkowicie określenie „zwyczajowe miejsce pobytu" (usual place of residence), które jest ważne z punktu widzenia dalszej operacjonalizacji pojęcia. Przedstawiony tutaj podział zasadza się na silnych arbitralnych kryteriach czasowych, które ponownie określane są przez formalną deklarację, dopełnienie konkretnych formalności - co nie zawsze jest dokonywane ${ }^{4}$.

${ }^{4}$ Pojawiają się tutaj kolejne problemy, ponieważ w literaturze (i słownikach różnych organizacji) wypracowano określenie: „migracja wahadłowa/cyrkulacyjna/czasowa”. W skrócie oznacza ono powtarzalne przemieszczanie się między dwoma: miastami, regionami, państwami. Zazwyczaj 
- Legalna/nielegalna - oba terminy definiowane są prosto; pierwszy (,migracja legalna” - legal migration) za EMN brzmi następująco: ,[m]igracja w zgodzie z właściwą ramą prawną” (EMN 2014: 178). Interesujące, że definicja „migracji nielegalnej” (irregular migration; tłumaczenie na język polski jako „migracja nieregularna" zdaje się kłaść nacisk na zupełnie inny, niż prawny, wymiar tego pojęcia, dlatego też należy podejść do tego ostrożnie lub odrzucić takie thumaczenie) została przez EMN wywiedziona ze słownika Międzynarodowej Organizacji do Spraw Migracji [MOSM/IOM], gdzie brzmi następująco: „,[p]rzemieszczanie się ludności do nowego miejsca zamieszkania lub tranzytu, które ma miejsce poza normami regulacyjnymi państw wysyłających, tranzytowych i przyjmujących" (EMN 2014: 173). Z punktu widzenia niniejszego artykułu istotna jest jednak płynność między obiema kategoriami. Status nielegalności może zostać nabyty na trzy sposoby: poprzez nielegalne przybycie do danego kraju (illegal entry), poprzez przekroczenie czasu legalnego pobytu na podstawie wizy (visa-overstay), poprzez niezastosowanie się do postanowień ściśle związanych z podstawą umożliwiającą legalny pobyt (Vo11 m e r 2011: 3). Zwróćmy uwagę, że w pierwszym przypadku różne mogą być przyczyny owej nielegalności: fałszerstwo, przemilczenie, kłamstwo, pominięcie punktu kontrolnego itd. Co więcej, wybiegając nieco do przodu i rozważając przypadek migracji przymusowej, uchodźcy mogą wkroczyć do danego kraju nielegalnie, ale w celu uzyskania w końcu legalnego statusus. W innych przypadkach także istnieje możliwość zalegalizowania pobytu po czasie, w tym odgórnie, np. dzięki zabiegom abolicyjnym. W drugim przypadku imigranci przechodzą ze statusu pobytu legalnego do nierejestrowanej imigracji nielegalnej, chociaż nie wyklucza się oczywiście, że ostatecznie powrócą do pełnej legalności. Ostatni przypadek obejmuje liczne sytuacje, kiedy legalny pobyt był powiązany z konkretnymi warunkami, jakie imigrant był zobowiązany spełnić: np. określona liczba godzin pracy, praca w określonym zakładzie/ mieście itd. (ta mże: 3; Kraler, Reichel 2011: 99-100). Można wobec tego

takie wyprawy są krótsze niż migracje krótkookresowe, niezwiązane ze zmianą stałego miejsca zamieszkania. Jednak jeśli pobyt jest wielokrotnie powtarzany, taka osoba może de facto spędzać porównywalną ilość czasu w obu tych miejscach. Tego typu przemieszczenia są trudne do uchwycenia, głównie dlatego, że niektóre definicje zawierają wyłączenia podróży określonego rodzaju, i nierzadko zdarza się, że migranci wahadłowi podpadają pod którąś z nich (K a c z m a r c z y k 2002: 5-8). Kluczowa pozostaje jednak regularność jako cecha wyróżniająca, czas takich przemieszczeń może być zatem różny. Wyodrębnić można kilka typów takich migracji czasowych: dojazdy do pracy, migracja sezonowa, cykliczna itd., zróżnicowanych ze względu na stopień regularności i czas przemieszczenia (t a m ż e: $11-12$ ).

${ }^{5}$ Więcej informacji na temat statusu prawnego i jego znaczenia (oraz płynności) w: K u p i s ze w s k a (2009); K a c z m a r c z y k (red.) (2014); D o b s o n, L a th a m, S a lt (2010). Problemy takie dotyczą zarówno obywatelstwa, jak i długości pobytu, ochrony międzynarodowej, statusu rezydenta, wydaleń z kraju i wielu innych kwestii z tym związanych, jak np. powiązania okresu przebywania w danym kraju z możliwościami pozyskania obywatelstwa, statusu rezydenta, pewnych praw itd. 
zauważyć, iż okresowo zasoby migracyjne zmieniają swe wartości niezależnie od faktycznej liczebności migrantów, gdyż zabiegi formalne wyłączają kategorie tych osób o nieuregulowanym statusie, przez co bazy danych stają się ślepe na część badanej populacji. Jest to zrozumiałe i zostanie szerzej opisane dalej. Działa to oczywiście w dwie strony - osoby o bazowo nielegalnym statusie mogą stać się migrantami legalnymi i ujmowanymi w oficjalnych statystykach. Jak zostanie pokazane $\mathrm{w}$ dalszej części tekstu, inaczej gromadzi się dane na temat strumieni, a inaczej na temat zasobów migracyjnych. Wtedy też jaśniejsze staną się zależności i znaczenie prezentowanych tutaj rozważań.

- Dobrowolna/przymusowa - w tym przypadku spotykamy jedynie definicję tego, czym jest „migracja przymusowa” (forced migration) za EMN, która została zaczerpnięta z rekomendacji IOM: ,[r]uch migracyjny, w którym istnieje element przymusu, włączając w to zagrożenie życia i środków do życia, czy to wynikające z przyczyn naturalnych, czy też działalności człowieka (np. ruchy uchodźców i wewnętrznie wysiedlonych, a także ludzi wysiedlonych z powodu naturalnych bądź środowiskowych katastrof, katastrof chemicznych i nuklearnych, głodu lub projektów rozwojowych)" (EMN 2014: 131, za Perruchoud, Redpath-Cros s 2011: 39). Termin ten należy zatem rozumieć szeroko, głównie ze względu na wzmiankę o ,środkach do życia”. Wobec tego do przymusowych możemy zaliczyć również te migracje, dla których bezpośrednią przyczyną jest trudna sytuacja ekonomiczna, a ona $\mathrm{z}$ kolei wynika $\mathrm{z}$ jakiegoś innego $\mathrm{z}$ wymienionych elementów. Można zatem przyjąć, że pozostałe migracje są rozumiane jako dobrowolne, chociaż warto pamiętać o tym, iż decyzja o podjęciu migracji zasadza się w dużej mierze na czynnikach ekonomicznych, gdzie badani mogą wskazywać na swego rodzaju „przymus”. Poza samą trudnością w przyporządkowywaniu migrantów do jednej z tych kategorii, trzeba też określić stopień legalności (dopuszczalności) takiego międzynarodowego przemieszczenia, zwłaszcza jeśli wdamy się w dyskusję nad rozważaniami z zakresu studiów nad uchodźstwem (refugee studies) ${ }^{6}$.

${ }^{6}$ Dużo fermentu powstało wokół takiego oto problemu: czy imigranci i uchodźcy w istocie są tym samym (tj. czy uchodźcy są kategorią przynależną do imigracji)? Nie ulega wątpliwości, że uchodźstwo należy do kategorii migracji przymusowych i powinno być od imigracji odróżnione (F e 11 e r 2005: 27; C h a t t y, M a r fl e e t 2013: 11). Problem leży jednak w dalszym definiowaniu pojęć z obszaru studiów nad migracjami, gdzie pojawia się kategoria „azylantów” (asylum seeker) (Voutira, D o ná 2007: 163; F ell e r 2005: 27, 29). Trudności nastręcza odróżnienie odmiennych typów migrantów pod kątem prawnym, tj. w znaczeniu legalności i nielegalności (zatem faktyczny problem zostaje strywializowany administracyjnie do rozróżnienia na migrantów legalnych i nielegalnych) oraz międzynarodowym, tj. w znaczeniu rozpoznania i zastosowania określonych środków ochronnych. Kontrowersje te wpływają natomiast na rozmywanie się tej kategorii w niektórych bazach danych (a być może należałoby powiedzieć, iż w większości tych, które na tym problemie nie są skupione), gdyż zostaje ona uproszczona i wprowadzona do innych, bardziej ogólnych zbiorów. Ponadto, trudności wydają się związane raczej ze strumieniami migracyjnymi niż z zasobami, ponieważ to przewidywanie kierunków uchodźstwa, zarówno w sensie tranzytowym, jak i docelowym, jest istotne dla rządzących - na poziomie krajowym oraz bytów ponadnarodowych. 
Kończąc rozważania na temat terminologii i związanych z nią problemów, warto dodać jeszcze kilka słów. Pominięte zostały rozważania nad innymi jeszcze typami migracji: rodzinnymi, zmierzającymi do unifikacji rodziny, ekonomicznymi, pracowniczymi, edukacyjnymi, łańcuchowymi itd. Oczywiście, są one istotne, lecz dotyczą raczej kwestii problemowych poszczególnych badań, niż trudności ogólnych związanych ze sferą pojęciową w analizach statystycznych. Istnieje cała gama problemów i terminów używanych w badaniach nad migracją - przede wszystkim są to kwestie takie, jak: określenie miejsca zamieszkania (ponieważ może to zostać różnie ujęte), określony charakter przekroczenia granicy, zmiana statusu rezydencjalnego itd.

Celem tego obszernego podrozdziału było pokazanie, jak wiele trudności wpływających na pomiar, fragmentaryzację, niekompletność, złudność, porównywalność - i przede wszystkim znaczenie - danych ilościowych mają definicje, ich wielość i źródła. Informacje te trzeba mieć zawsze na uwadze, kiedy prowadzi się badania porównawcze (i nie tylko) w obszarze studiów nad migracjami.

\section{Sposoby badania migracji i fragmentaryzacja danych}

Wcześniejsze rozważania są ściśle związane ze sposobem pomiaru i zasięgiem danych zbieranych dla opracowań statystycznych. Jako przykład zostanie wykorzystany system badań migracji zagranicznych w Polsce, za który odpowiedzialny jest GUS. System ten konstytuują trzy podstawowe źródła: „[a]dministracyjne źródła danych ([r]ejestr PESEL, [s]ystem POBYT, oraz [i]nne rejestry administracyjne), [b]adania statystyczne (Badanie ludności zameldowanej na pobyt czasowy oraz nieobecnej w związku z pobytem czasowym za granicą, BAEL, EU-SILC, Spisy ludności, [i]nne badania), [z]agraniczne źródła danych ([b]aza danych Eurostatu, [s]tatystyki innych krajów, [z]agraniczne źródła administracyjne)" (GUS 2011: 2). Nie ma potrzeby omawiać ich wszystkich, a jest to wręcz niemożliwe w ramach krótkiego artykułu.

Jak łatwo można zauważyć, źródeł statystyk migracyjnych w Polsce jest wiele, co wynika z ich ograniczoności, przez co można stwierdzić, iż pozyskiwane dane są fragmentaryczne (Jaźwińska 2000: 4, 6). Rejestr PESEL gromadzi informacje o strumieniach migracyjnych (i to tylko tych na pobyt stały). Istotny

\footnotetext{
Próby takich przewidywań opierają się na potężnych modelach obliczeniowych, ujmujących wiele zmiennych, które mają pomóc w przewidywaniu i definiowaniu pod względem różnych cech przemieszczających się ludności (E d w a rd s 2008: 347-351). Warto zauważyć, iż w słowniku EMN używa się dwóch określeń: forced migrant i stranded migrant, które wedle tego słownika w obu przypadkach thumaczone jest na język polski jako „migrant przymusowy” - to kolejne potwierdzenie, że w zależności od tego, przez kogo są przygotowywane statystyki, różne kategorie osób mogą wchodzić do tych samych podgrup (EMN 2014: 131, 275).
} 
jest jednak nie sam moment migracji, a rejestracja (lub wymeldowanie) pobytu, następuje zatem separacja faktycznego czasu migracji od jej ujęcia w tych statystykach. Pozyskuje się takie informacje, jak: „kraj poprzedniego/docelowego pobytu, miejsce obecnego zameldowania na pobyt stały w Polsce (dla imigrantów), miejsce zameldowania na pobyt stały w Polsce przed wyjazdem (dla emigrantów), datę wymeldowania/zameldowania, płeć, wiek, stan cywilny i obywatelstwo osób migrujących" (GUS 2011: 1, 3). System POBYT ewidencjonuje cudzoziemców ze względu na specyficzny status prawny, np. przyznanie ochrony międzynarodowej, wizy, wydalenie danej osoby itd. (t a m ż e: 3). Co jednak najważniejsze, system ten stanowi źródło danych dla wymienionych wcześniej statystyk wymaganych przez Eurostat (na tym też opierają się szacunki liczby imigrantów w Polsce) ( $\mathrm{t}$ a $\mathrm{m} \dot{z} \mathrm{e})$. Inne rejestry administracyjne gromadzą informacje np. o repatriantach i osobach, które zostały obywatelami Polski w różny sposób, dopuszczalny jednak w naszym prawie (t a m że). Jak można wobec tego zauważyć, informacje te są dość skromne i raczej pomija się w nich zmienne społeczno-ekonomiczne; ponadto zasadzają się na aktach formalnych, obligatoryjnych - żeby nie powiedzieć, iż są zbierane ,przy okazji”. Podobnie wygląda sytuacja w przypadku zagranicznych źródeł danych, których trzon stanowią badania Eurostatu, niejednokrotnie zasadzających się na liczbach pochodzących właśnie ze źródeł administracyjnych innych państw, można zatem przyjąć, iż również napotkać możemy na fragmentaryczność i skromność informacji. Co więcej, korzystanie z nich powoduje te wszystkie problemy, które zostały wskazane wcześniej, tj. np. konieczność brania pod uwagę celu i specyfiki tamtejszych badań (ta m że: 10).

Pełniejsze i bardziej obiecujące są elementy w szerokiej kategorii badań statystycznych. Sama nazwa: „Badanie ludności zameldowanej na pobyt czasowy oraz nieobecnej w związku z pobytem czasowym za granicą" mówi, czego można się spodziewać. Warto dodać, że to właśnie tutaj problem stanowi wymóg zameldowania się, ponieważ wiele migracji jest nielegalnych, a te osoby, które migrują legalnie, nie zawsze dopełniają obowiązku zameldowania/wymeldowania (t a $\mathrm{m}$ ż e: 4). Jest to zatem stan prawny, nie zaś rzeczywisty. Oczywiście, badane są w tym przypadku zasoby migracyjne, a do pozyskiwanych danych należą (w przypadku imigrantów) „miejsce zameldowania na pobyt czasowy, kraj poprzedniego zamieszkania, zamierzony czas pobytu w Polsce, płeć, wiek, stan cywilny, wykształcenie i obywatelstwo imigrantów”; (w przypadku emigrantów) „miejsce stałego zameldowania w Polsce, kraj wyjazdu, zamierzony czas pobytu za granicą, płeć, wiek, wykształcenie i obywatelstwo osób migrujących" (t a m że).

Uwagę warto skupić na badaniu BAEL, które jest reprezentatywne i przeprowadzane zgodnie z metodyką Międzynarodowej Organizacji Pracy, co zapewnia porównywalność między państwami członkowskimi. Badanie to, podobnie jak inne, wyklucza pewne kategorie migrantów, wciąż jednak stanowi solidne źródło dla opisów trendów migracyjnych i może być używane do szacowania emigracji (t a m ż e: 5). Dane obejmują m.in.: „kraj urodzenia badanych osób [...], kraj 
obywatelstwa, miejsce zamieszkania na rok przed badaniem" (t a m ż e) ${ }^{7}$ (a w wydaniu polskim dodatkowo informacje o emigracji na pobyt czasowy). Potężnym źródłem danych są spisy ludności, które mierzą zarówno zasoby, jak i strumienie migracyjne. „Spis Powszechny” w 2002 r. dostarczył informacji o obywatelstwie i kraju pochodzenia, co umożliwiło stworzenie takich kategorii, jak: emigrant, imigrant, emigrant krótko- i długookresowy. W spisie z roku 2011 uwzględniono jeszcze więcej zmiennych, głównie ze względu na uczynienie zadość zobowiązaniom międzynarodowym i pozyskanie informacji takich, jak: „kraj/miejsce urodzenia, kraj posiadanego obywatelstwa, czy osoba kiedykolwiek mieszkała za granicą oraz rok przyjazdu do kraju (od 1980 r.), poprzednie miejsce zamieszkania i data przybycia do obecnego miejsca zamieszkania; lub miejsce zamieszkania na rok przed spisem powszechnym" (ta mże: 8). Dodatkowo zatem wyodrębniono kategorię migrantów powrotnych (t a mże: 9). Podobnie jak w przypadku BAEL, badanych jest wiele zmiennych społeczno-ekonomicznych, które mogą dostarczyć pełniejszego obrazu migranta, jednak podstawową wadą spisów jest 10-letni odstęp między kolejnymi edycjami.

Podsumowując ${ }^{8}$, łączenie poszczególnych źródeł danych nastręcza problemów z powodu odmiennych definicji, ,metodologii, zakresu pozyskiwanych danych, populacji, której dotyczą, klasyfikacji oraz interpretacji, a także dostępności danych" (ta mże: 10). Dane te są zatem złej jakości (K up iszewska 2009: 23-24) i mogą powodować np. badanie dwukrotnie tej samej populacji, tyle że pod inną nazwą. Poza tym bazy są niekompletne $z$ uwagi na luki w prawie i odmienne podejście do zbieranych danych.

\section{Uwagi końcowe}

Kończąc, trzeba zamieścić kilka dodatkowych, krótkich uwag, które nieco uzupełnią przedstawione treści. Pominięta została wcześniej kwestia prognozowania migracji. Marek Kupiszewski wskazuje, że z punktu widzenia demografii „przedmiotem prognozowania powinny być albo napływy i odpływy, albo migracje netto, albo zmiany wielkości populacji cudzoziemskich w krajach docelowych, albo wynikające z migracji zmiany populacji w krajach wysyłających"9

7 Zakres informacji jest szeroki, ponieważ badanie - poza wymienionymi zmiennymi - dotyczy przecież głównego problemu, czyli aktywności ekonomicznej ludności, podczas gdy bazy administracyjne takich informacji są pozbawione.

${ }^{8}$ System zbierania danych w Polsce jest rozbudowany, a opis wszystkich jego elementów przekracza zakres i potrzeby niniejszego artykułu. Pełniejszy opis problematyki w: K u p i s z e w s k a (2009).

9 Jak widać, problem może być badany z wielu stron. Warto przy tym pamiętać, iż również inne zmienne mogą wydawać się podobne, a jednak znacząco się różnią. Przykładowo można podać kwestie zamieszkania - czy chcemy się dowiedzieć o: ostatnim miejscu zamieszkania, ostatnim 
(K u p is zewski 2004: 30) ${ }^{10}$. Modele (np. ekonometryczne) wykorzystywane do prognozowania procesów migracyjnych mają wady, z których warto podkreślić jedną - nieuwzględnianie wystarczającej liczby czynników demograficznych i społecznych, co prowadzi do znacznych błędów statystycznych (t a m że: $26,28)$, zarówno jeśli chodzi o badanie strumieni ${ }^{11}$, jak i zasobów migracyjnych.

Ewa Jaźwińska w swoim tekście (Jaźwiń s ka 2000) ${ }^{12}$ opisuje wiele podstawowych kwestii związanych z ilościowym badaniem migracji w kontekście kolejnych etapów badawczych. Przede wszystkim warto przytoczyć kilka pytań, które zdaniem autorki badacz powinien sobie zadać podczas wybierania populacji do badania: „czy badani mają być tylko migranci?”, „czy badaniami objąć również tych, co nie migrują?”, „kto jest migrantem?” (t a m ż e: 15) (chodzi o to, czy badać osoby, które migrację zakończyły; te, które chcą w przyszłości podjąć taką próbę; czy też te, które w jakiś sposób są w stanie określić siebie jako migrujących w tej chwili); czy badać samych migrantów, czy również społeczność, z której pochodzą (i do której przybywają)? (t a mże). Są to niezwykle istotne pytania, zwłaszcza jeśli chcemy uzyskać coś więcej, niż tylko opis danej populacji, ale np. uchwycić zmianę, cechy specyficzne kategorii migrantów, przyczyny, przebieg i skutki migracji itd. Innym, chociaż nieco mniej aktualnym problemem jest dostępność odpowiedniego operatu losowania. Takie zbiory dotyczą bardzo konkretnych spraw w przypadku migrantów, jak np. wizy, zezwolenia na pobyt, zezwolenia na pracę itd. Trudno zatem dotrzeć do wyczerpującego operatu, który obejmowałby wszystkie kategorie migrantów i choćby podstawowe cechy demograficzne (w zależności od sposobu doboru próby) (t a m ż e: 16-17). W kontekście polskim możliwe jest np. skorzystanie z bazy PESEL, która jednak gromadzi informacje jedynie o zameldowanych migrantach, co jest zdecydowanym ograniczeniem. System POBYT również ma swoje mankamenty, jak choćby powszech-

miejscu zameldowania, ostatnim miejscu zwyczajowego pobytu, czy też o aktualnym miejscu zamieszkania/zameldowania/zwyczajowego pobytu. Wszystkie odnoszą się do kategorii zamieszkania, ale mówią coś zupełnie innego. Podobnie jest z różnymi kategoriami migracyjnymi, co w połączeniu z różnorodnością definicji powinno uczulać każdego badacza na przeglądanie metodologii stojącej za każdym badaniem.

${ }^{10}$ Trzeba zauważyć, iż zasoby, strumienie i migracja netto nie są jedynymi wartościami, które są mierzone. Poza tymi miarami, wymienionymi przez Kupiszewskiego, warto wspomnieć o istnieniu „współczynnika salda migracji” (crude rate of net migration), „mieszanych przepływach migracyjnych” (mixed migration flow), ,migracji brutto” (total migration) (EMN 2014: 73, 196, 286).

${ }^{11}$ Osobnym problemem jest jeszcze mierzenie strumieni migracyjnych w przypadku przemieszczeń nieuregulowanych (nielegalnych). Z jednej strony bowiem możemy mówić o przepływach międzynarodowych, ale w pewnym sensie strumienie występują na poziomie narodowym, kiedy mówimy o zmianie statusu, tj. z uregulowanego na nieuregulowany, i odwrotnie. Do pewnego stopnia ten problem również może podlegać zabiegom prognostycznym $(\mathrm{Kraler}$, R e i c h el 2011: 99-102).

${ }^{12} \mathrm{Z}$ punktu widzenia problematyki niniejszego artykułu tekst ten jest stosunkowo stary, lecz zawiera wiele aktualnych i cennych uwag. 
ny problem migrantów nielegalnych ${ }^{13}$. Odnosząc się jeszcze do przytoczonych wcześniej pytań (i zarzutów wobec jednostronności modeli ekonometrycznych), trzeba zwrócić uwagę, że odpowiedź na nie często będzie determinowała podstawowe jednostki analizy. Mogą to zatem być jednostki lub całe gospodarstwa domowe. Jest to o tyle istotne, że istnieje ścisły związek między wyborem jednej $\mathrm{z}$ tych opcji a teoriami na temat migracji (t a m ż e: 16). Dla przykładu, postrzeganie migracji jako decyzji jednostki sterowanej czynnikami ekonomicznymi jest charakterystyczne dla koncepcji neoklasycznej i badań ekonomicznych (wiara w homo oeconomicus) (C a s t l e s, Mill e r 2011:41-42). Z drugiej strony, gospodarstwa domowe są powiązane z tzw. „nową ekonomiką migracji pracowniczych" oraz „teorią sieci migracyjnych”, gdzie wskazuje się na czynniki zakorzenione w samej społeczności, z jakiej migrant się wywodzi; innymi słowy - decyzje o migracji podejmuje rodzina, wspólnota, a nie migrant sam $w$ sobie ${ }^{14}$ ( $\mathrm{t}$ a $\mathrm{m}$ ż e: $44-45$, 49-50). Do analizy w tym drugim przypadku zostają zatem włączone zaniedbywane w modelach ekonometrycznych zmienne społeczne i demograficzne ${ }^{15}$.

\section{Zakończenie}

Podsumowując, można powiedzieć, że badania nad współczesnymi migracjami są istotnym, potrzebnym i trudnym obszarem. Pomijając samą zmienność przedmiotu i podmiotów badania, ilościowa perspektywa napotyka na liczne problemy. Artykuł miał na celu uwypuklić te, które - choć nie zawsze specyficzne tylko dla niej - są jednak wyjątkowo istotne. Precyzyjność definicji jest jednym z takich elementów i chociaż przytaczane znaczenia terminów w większości przypadków spełniają ten wymóg, to ich wielość i różny stopień zobligowania nimi

${ }^{13}$ Problem ten może być częściowo zneutralizowany poprzez zarzucenie badań reprezentatywnych i korzystanie z doboru celowego ( J a ź w i ń s k a 2000: 28). Sam problem niedoskonałości operatu można próbować obejść poprzez korzystanie z kilku operatów i podzielenie badania na etapy (t a m ż e: 27).

${ }^{14}$ Należy dodać, iż same jednostkowe dane na temat migracji niekiedy pokazują jedynie część informacji. Czasami daje się ustalić, czy dana osoba jest oryginalnym migrantem, czy np. osobą $\mathrm{z}$ pochodzeniem migracyjnym ( $\mathrm{w}$ drugiej generacji). Uwzględnienie większej liczby czynników może też pozwolić na ustalenie, czy mamy do czynienia w przypadku konkretnej osoby z „migracją rodzinną" (całej rodziny naraz), czy też z „łączeniem rodzin” (kiedy do oryginalnego migranta dociera po pewnym czasie jego rodzina) (EMN 2014: 126-127). Jeszcze innym przypadkiem jest tzw. „migracja łańcuchowa”, gdzie (w pierwotnym brzmieniu) oryginalny migrant pomaga kolejnym migrantom $\mathrm{z}$ danego państwa osiedlić się w kraju przyjmującym (zwykle w tej samej okolicy) (t a m ż e: 49). Informacje te są cenne z punktu widzenia prognozowania, polityki imigracyjnej i społecznej oraz pewnych planów rozwojowych, urbanistycznych i kontrolnych.

${ }^{15}$ Więcej informacji na temat różnych sposobów doboru próby, ich zalet i wad, a także opisu możliwości wykorzystania poszczególnych technik badawczych w ilościowym badaniu migracji w: J áz i ń s k a (2000). 
podczas badań nastręcza trudności. To z kolei prowadzi do znacznej fragmentaryzacji danych i ich niepewności (co do interpretacji i sposobu pozyskiwania). Brak harmonizacji (czy raczej jej wielokrotne próby) skutkuje koniecznością uwzględniania informacji z wielu systemów gromadzenia danych, co nie zawsze jest możliwe. Nachodzenie na siebie poszczególnych kategorii migrantów, brak spójności metodologicznej, różny rygor gromadzenia danych administracyjnych skutecznie utrudnia tak istotne badania porównawcze. Innymi słowy, trzeba zawsze brać pod uwagę kontekst powstania poszczególnych baz danych, aby zrozumieć, co stoi za danymi i co jesteśmy w stanie z nimi zrobić. Bez tego wszelkie rekomendacje dla polityki społecznej i imigracyjnej, działania planistyczne i prognostyczne nie powiodą się. Dlatego tak istotna jest wzmożona praca zarówno nad rozwojem sposobów badania migracji, jak i poprawą już istniejącego procesu badawczego. Migracje były, są i będą obecne, tym bardziej, że współcześnie starzejące się społeczeństwa będą wcześniej czy później musiały przyciągnąć na swoje terytorium ludzi młodych, których im brakuje oraz stworzyć warunki ich spokojnej integracji. Stąd też warto mieć rzetelne informacje na temat przemian i charakteru obecnych procesów migracyjnych.

\section{Bibliografia}

B a r c z J., Górka M., Wy ro zu m sk a A. (2012), Instytucje i prawo Unii Europejskiej. Podręcznik dla kierunków prawa, zarządzania i administracji, LexisNexis Polska, Warszawa.

C a s tl e s S., M i 11 e r M. J. (2011), Migracje we współczesnym świecie, Wydawnictwo Naukowe PWN, Warszawa.

Chat ty D., Marfle et P. (2013), Conceptual problems in forced migration, „Refugee Survey Quarterly", Vol. 32, No. 2, s. 1-13, http://rsq.oxfordjournals.org/content/32/2/1.full.pdf +html, 15.04.2015.

D o b s o n J., L a th a m A., S a lt J. (2010), European Migration Network Annual Report on Asylum and Migration Statistics for the UK 2007, Home Office UK Border Agency, London, http://www.geog.ucl.ac.uk/research/transnational-spaces/migration-research-unit/publications/pdfs/27._UNITED_KINGDOM_Annual_Report_on_Asylum_and_Migration_Statistics_2007_FINAL_Version_March2010.pdf, 15.04.2015.

D zi ięglew s ki M. (2012), Współczesne studia migracyjne jako wielowymiarowa układanka, „Annales Universitatis Paedagogicae Cracoviensis. Studia Socologica IV”, t. 2, s. 7-13, http:// www.ifis.up.krakow.pl/studia_sociologica/images/SS_IV_2/Dzieglewski1.pdf, 15.04.2015.

E d w a r d s S. (2008), Computational Tools in Predicting and Assessing Forced Migration, „Journal of Refugee Studies”, Vol. 21, No. 3, s. 347-359, http://jrs.oxfordjournals.org/content/21/3/347. full.pdf+html, 15.04.2015.

European Migration Network (2014), Asylum and Migration Glossary 3.0, European Commission, http://ec.europa.eu/dgs/home-affairs/what-we-do/networks/european_migration_network/ docs/emn-glossary-en-version.pdf, 15.04.2015.

Eurostat (2015), Concepts and Definitions. Eurostat's Concepts and Definitions Database, http:// ec.europa.eu/eurostat/ramon/nomenclatures/index.cfm?TargetUrl=LST_NOM_DTL_GLOSSARY \&StrNom=CODED2\&StrLanguageCode=EN, 11.04.2015. 
F e 11 e r E. (2005), Refugees are not migrants, „Refugee Survey Quarterly”, Vol. 24, No. 4, s. $27-$ 35, http://rsq.oxfordjournals.org/content/24/4/27.full.pdf $+h t m l, 15.04 .2015$.

Główny Urząd Statystyczny (2011), Departament Badań Demograficznych - Wydział Analiz i Badań Migracji, System badań migracji zagranicznych w Polsce, http://stat.gov.pl/obszary-tematyczne/ludnosc/migracje-ludnosci/system-badan-migracji-zagranicznych-w-polsce, 7,1.html, 11.04.2015.

Główny Urząd Statystyczny (2015), Definicje pojęć, http://stat.gov.pl/metainformacje/slownik-pojec/definicje-pojec, 11.04.2015.

Henning S., Hovy B. (2011), Data Sets on International Migration, „International Migration Review", Vol. 45, No. 4, s. 980-985, http://onlinelibrary.wiley.com/doi/10.1111/ j.1747-7379.2011.00874_2.x/full, 15.04.2015.

J a ź w iń s k a E. (2000), Metody ilościowe w badaniach nad migracjami międzynarodowymi, Instytut Studiów Społecznych Uniwersytetu Warszawskiego, Warszawa, http://www.migracje. uw.edu.pl/download/publikacja/248, 15.04.2015.

K a c z m a r c z y k P. (2002), Migracje o charakterze cyrkulacyjnym a inne formy mobilności terytorialnej w świetle doświadczeń badawczych, Instytut Studiów Społecznych Uniwersytetu Warszawskiego, Warszawa, http://www.migracje.uw.edu.pl/publ/579, 15.04.2015.

K a c z m a r c z y k P. (red.) (2014), Recent Trends in International Migration in Poland. The 2012 SOPEMI Report, Ośrodek Badań nad Migracjami, Warszawa, http://www.migracje.uw.edu.pl/ $\mathrm{publ} / 2373,15.04 .2015$.

K ing R. (2012), Theories and Typologies of Migration: An Overview and a Primer, Malmö Institute for Studies of Migration, Diversity and Welfare, Malmö, https://www.mah.se/upload/ Forskningscentrum/MIM/WB/WB\%203.12.pdf, 15.04.2015.

K r a 1 e r A., R e i c h e 1 D. (2011), Measuring Irregular Migration and Population Flows - What Available Data Can Tell, „International Migration”, Vol. 49, No. 5, s. 97-128, http://onlinelibrary.wiley.com/doi/10.1111/j.1468-2435.2011.00699.x/full, 15.04.2015.

K u p is zew s k a D. (2009), Data Collection Systems and Practices in Poland Relevant to Research on Migration and Integration, Central European Forum for Migration and Population Research, Warszawa, http://www.cefmr.pan.pl/docs/cefmr_wp_2009-03.pdf, 15.04.2015.

K u p is ze w sk i M. (2004), Metodologiczne problemy prognozowania migracji zagranicznych, „Zeszyty Naukowe”, t. 15, Kolegium Gospodarki Światowej Szkoły Głównej Handlowej, Warszawa, http://yadda.icm.edu.pl/yadda/element/bwmeta1.element.dl-catalog-0e0bc6b2-9ce8-4b9e-b078-25fc96a13e55/c/Zeszyty_Naukowe_SGH-2004-9-15-21-34.pdf, 15.04.2015.

Perruchoud R., Redpath-C ros s J. (eds.) (2011), Glossary on Migration, $2^{\text {nd }}$ ed., IOM International Organization for Migration, Geneva, http://www.epim.info/wp-content/uploads/2011/01/iom.pdf, 15.04.2015.

United Nations (UN) (1998), Department of Economic and Social Affairs, Statistics Division, Recommendations on Statistics of International Migration, Revision 1, United Nations, New York, http://unstats.un.org/unsd/publication/SeriesM/seriesm_58revle.pdf, 15.04.2015

Varg a s-S i 1 v a C. (2012), EU Migrants in other EU Countries: An Analysis of Bilateral Migrant Stocks, The Migration Observatory at the University of Oxford, http://www.migrationobservatory.ox.ac.uk/sites/files/migobs/EU\%20migrant\%20stocks.pdf, 15.04.2015.

Vo $11 \mathrm{~m}$ e r B. (2011), Irregular Migration in the UK: Definitions, Pathways and Scale, The Migration Observatory at the University of Oxford, http://www.migrationobservatory.ox.ac.uk/sites/ files/migobs/Briefing\%20-\%20Irregular\%20Migration_0.pdf, 15.04.2015.

Vo u t i r a E., D o ná G. (2007), Refugee Research Methodologies: Consolidation and Transformation of a Field, ,Journal of Refugee Studies”, Vol. 20, No. 2, s. 163-171, http://jrs.oxfordjournals.org/content/20/2/163.full.pdf + html, 15.04.2015. 


\title{
Jakub Krzysztof Adamski
}

\section{DIFFICULTIES CONCERNING QUANTITATIVE RESEARCH IN CONTEMPORARY MIGRATION STUDIES. SELECTED ISSUES}

\begin{abstract}
The purpose of this article is to show those dealing with issues of contemporary migration studies, what are the basic difficulties arising from quantitative research in this field. Issues concerning definitions are tended to with the most focus. These are best described as multilayered, but aside from problems with deciding the meaning of a given concept, there is a number of influences that come into play - political (teleological), legal, practical, process-wise and temporal. For those reasons, all of the above serve as a point of departure for comments made in regard to measurements, interpretations, access, controversies, and inconsistent and low-quality information found in databases. As a result, data dispersion and fragmentation becomes a nuisance, which significantly hinders the ability to carry out comparative research, both between countries as well as different categories of citizens of a given country. Also discussed is a token data-mining system on the issues of foreign migration. Closing arguments touch on a several chosen aspects of an actual research process, relevant from the standpoint of contemporary migration studies. This reconstruction refers to both Polish and European contexts.
\end{abstract}

Keywords: quantitative research, migrations, immigration, emigration, databases. 